\title{
RESEARCH PAPER \\ Resistance assessment of grapevine rootstocks used in Chile to the root-knot nematodes Meloidogyne ethiopica, M. hapla, and $M$. javanica
}

\author{
Erwin Aballay, and Oscar Vilches \\ Facultad de Ciencias Agronómicas, Universidad de Chile, Casilla 1004, Santiago, Chile
}

\begin{abstract}
E. Aballay, and O. Vilches. 2015. Resistance assessment of grapevine rootstocks used in Chile to the root-knot nematodes Meloidogyne ethiopica, M. hapla, and M. javanica. Cien. Inv. Agr. 42(3): 407-413. The rootstocks 1103 P, 101-14, K 5BB, SO4, and 3309 were assessed to determine their resistance to the three common Meloidogyne species present in Chilean vineyards, M. ethiopica, the most frequent species, M. hapla and M. javanica. Their response was compared to three ungrafted cultivars, Thompson Seedless, Pinot Noir and Chardonnay. To perform this study, two month-old plants produced from cuttings were inoculated with 5,000 eggs per 3-L pots, filled with steamed substrate and kept in a glasshouse covered with a black mesh to intercept $30 \%$ of sun light and avoid heating of the substrates. After a growth period of six months, plants were removed from the pots, and resistance was determined by measuring root weights, the number of galls and eggs per g of root, and second stage juveniles per 250 $\mathrm{cm}^{3}$ of soil. Results showed that the five rootstocks were resistant to the parasitism of the three Meloidogyne species, since their reproduction was limited and differed from two of the cultivars. Chardonnay was the most susceptible cultivar, mainly to the high level of parasitism by M. ethiopica, while Pinot Noir was moderately susceptible and Thompson Seedless showed the lowest susceptibility.
\end{abstract}

Key words: Plant-parasitic nematodes, root pests, Vitis vinifera, vineyards.

\section{Introduction}

Grapevine (Vitis vinifera) is one of the most important crops in Chile, cultivated for table grape as well as wine and liquor production. Several genera and species of plant-parasitic nematodes have been reported to cause economic damage and to be present in the area under cultivation (Aballay et al., 2009). Meloidogyne species are frequently

Received April 13, 2015. Accepted July 31, 2015. Corresponding author: erwin.aballay@gmail.com detected in root systems of grape plants and are especially harmful in wine grape cultivars, such as Chardonnay, Cabernet Sauvignon, Merlot, Sauvignon Blanc and Shiraz. Some table grape cultivars, such as Red Globe and Flame Seedless, are also very susceptible to root-knot nematodes and are frequently associated with the fungi responsible for black-foot disease and grapevine decline (Scheck et al., 1998; Montealegre et al., 2009). M. ethiopica is the most frequently detected root-knot species, and for many years, it was identified as M. incognita, M. arenaria or M. javanica, due to similar 
morphological characteristics and its response to differential host test (Carneiro et al., 2004, 2007). More than $99 \%$ of the vineyards infested with this genus show the presence of $M$. ethiopica (Carneiro et al., 2007). It has been observed that M. ethiopica is more aggressive than other Meloidogyne species present in Chile, as evidenced by the larger size of galls on the roots, the number of eggs per gram of roots and the premature decline of plants. Multiple classical control methods and strategies are employed for infested soils including the use of fallow, organic amendments, non-fumigant nematicides and others (Alvarez, 2006).

Under replanting conditions, the use of resistant rootstocks is a good alternative, although these control measures are not extensively applied by most growers for several reasons, among them the absence of the insect root pest filoxera Daktilosphaera vitifolii in Chilean vineyards (Aballay et al., 2009). Additionally, a given rootstock is not resistant and/or tolerant to all nematodes, e.g., Xiphinema index or Mesocriconema xenoplax. Finally, it is not clear whether rootstocks have a similar level of resistance to all Meloidogyne species.

Meloidogyne species may exhibit differences in pathogenicity in the same host (Roberts, 1995). It is noteworthy that the most common species, $M$. incognita, M. hapla, M. javanica and M. arenaria are also present in the country, and previous tests did not consider the relevant presence of $M$. ethiopica (Aballay et al., 1997).

The purpose of this study was to assess the resistance of five grapevine rootstocks used in Chile to M. ethiopica, M. hapla and M. javanica, three species present in vineyards in Chile, and to compare their response with three ungrafted cultivars.

\section{Materials and methods}

Five grapevine rootstocks and three commercial cultivars (controls) were evaluated for resistance to three Meloidogyne species: $1103 \mathrm{P}$ ( $V$. berlandieri $x$ V. rupestris), 101-14 (V. riparia $x$ V. rupestris), Kober 5BB ( $V$. berlandieri x V. riparia), 3309 ( $V$. riparia $\mathrm{x} V$. rupestris), $\mathrm{SO} 4(V$. berlandieri $\mathrm{x} V$. riparia), Chardonnay ( $V$. vinifera), Pinot Noir $(V$. vinifera) and Thompson Seedless ( $V$. vinifera). Plants were obtained from dormant wood cuttings collected in winter from different vineyards and nurseries and rooted in sterile perlite. Once rooted, the plants were transplanted into steamed 1:1:1 (v/v) sand: agriculture soil: organic matter mix in 3.0-L pots and kept in a glasshouse.

After two months of growth, plants were inoculated with the nematode pure species inoculum, obtained from tomato, kiwi plants and grapevines for M. javanica, M. hapla and M. ethiopica, respectively. Eggs were extracted from the roots according to the method described by Hussey and Barker (1973) and inoculated in a water suspension of $10 \mathrm{~mL}$ at a dose of 5,000 eggs per pot with a pipette through 5 holes dug in the soil around the plant.

Once inoculated, plants were grown in a shaded $10 \mathrm{~m} \times 20 \mathrm{~m}$ greenhouse covered by a raschel mesh, which intercepted $30 \%$ of sunlight and prevented overheating of plants and pots. Plants were watered once or twice per week, depending on the temperature. The maximum and minimum temperature outside the greenhouse in mid-summer were approx. 34 and $15{ }^{\circ} \mathrm{C}$, respectively, and within the greenhouse 28 and $18^{\circ} \mathrm{C}$, respectively.

Each rootstock or grape cultivar was inoculated with the three species of Meloidogyne.

The capacity of nematodes to parasitize and reproduce in every rootstock or cultivar was determined at the end of the growing season of the grape plants in early autumn, approximately 6 months after inoculation, by determining the number of second stage juveniles in the soil, along with eggs and galls in the roots. Plants were carefully removed from containers, and the 
roots were separated from the canopy, washed and fresh weighed. The number of galls per plant was counted, and eggs were extracted from roots according to the Hussey and Barker method (1973).

The soil from each pot was mixed, and a 250 $\mathrm{cm}^{3}$ sample was taken to quantify the number of juveniles present, combining the soil sieving and decanting method with Baermann's funnel (Southey, 1986). Counting was performed using a dissecting microscope Carl Zeiss Stemi 2000 $\mathrm{C}$ at 50-90 $\mathrm{x}$ magnification.

The experiment was set up in a completely randomized design with factorial structure and 4 replicates, where the two factors are rootstockscultivar and nematode species $(8 \times 3)$. Data were analyzed separately for each nematode species and rootstock/cultivar with one-way Analysis of Variance (ANOVA). When F values were significant, differences between means were evaluated using Tukey's Multiple Range $(\mathrm{P} \leq 0.05)$. Experiments were repeated twice, with two sets of pots, and the data presented correspond to the average of both experiments. Minitab ${ }^{\circledR}$ V16 was used for data analysis.

\section{Results}

Results from the experiments are presented in Table 1, showing the reproduction parameters with the significance for each combination cultivar nematode species. The analysis showed that there was an interaction between both factors $(\mathrm{P} \leq 0.05)$.

Differences were not observed among rootstocks in relation to each of the Meloidogyne species, exhibiting the same population levels measured through the three parameters evaluated. This clearly indicates that there were no differences in the reproductive capacities of M. ethiopica, $M$. hapla and M. javanica on any of the rootstocks $(\mathrm{P} \leq 0.05)$. Apparently, none of the rootstocks were immune, since the three nematode species were able to reproduce to a limited extent.

Two cultivars were more susceptible to the three Meloidogyne species compared with the rootstocks, in spite of differences between them. Thompson Seedless was the most resistant, not showing differences with the five rootstocks for M. hapla and $M$. javanica in the number of galls, while it was more resistant than Chardonnay but more susceptible than the rootstocks to M. ethiopica.

Table 1. Reproduction of Meloidogyne spp. in five rootstocks and three grape cultivars.

\begin{tabular}{|c|c|c|c|c|c|c|c|c|c|}
\hline \multicolumn{4}{|c|}{ Galls g of roots ${ }^{-1}$} & \multicolumn{3}{|c|}{ Eggs $g$ roots $^{-1}$} & \multicolumn{3}{|c|}{ Second stage juveniles $250 \mathrm{~cm}^{-3}$ soil } \\
\hline $\begin{array}{l}\text { Rootstocks } \\
\text { and } \\
\text { cultivars }\end{array}$ & $\begin{array}{c}M . \\
\text { ethiopica }\end{array}$ & M. hapla & $\begin{array}{c}M . \\
\text { javanica }\end{array}$ & M. ethiopica & M. hapla & M. javanica & $\begin{array}{c}M . \\
\text { ethiopica }\end{array}$ & M. hapla & $\begin{array}{c}M . \\
\text { javanica }\end{array}$ \\
\hline $1103 \mathrm{P}$ & $0.39 \mathrm{aA}$ & $0.33 \mathrm{aA}$ & $0.18 \mathrm{abA}$ & $12.43 \mathrm{aA}$ & $19.83 \mathrm{aA}$ & $5.86 \mathrm{aA}$ & $7.75 \mathrm{abA}$ & $8.50 \mathrm{aA}$ & $7.38 \mathrm{aA}$ \\
\hline $\mathrm{SO} 4$ & $1.04 \mathrm{aA}$ & $0.20 \mathrm{aA}$ & $0.14 \mathrm{abA}$ & $32.36 \mathrm{aA}$ & $44.37 \mathrm{aA}$ & $41.16 \mathrm{aA}$ & $7.50 \mathrm{abA}$ & $5.50 \mathrm{aA}$ & $4.13 \mathrm{aA}$ \\
\hline $101-14$ & $0.15 \mathrm{aA}$ & $0.10 \mathrm{aA}$ & $0.04 \mathrm{bA}$ & $34.66 \mathrm{aA}$ & $31.26 \mathrm{aA}$ & $23.04 \mathrm{aA}$ & $5.75 \mathrm{bA}$ & $9.25 \mathrm{aA}$ & $12.25 \mathrm{aA}$ \\
\hline K 5BB & $0.42 \mathrm{aA}$ & $0.35 \mathrm{aA}$ & $0.19 \mathrm{abA}$ & $48.56 \mathrm{aA}$ & $106.41 \mathrm{aA}$ & $62.66 \mathrm{aA}$ & $13.13 \mathrm{abA}$ & $7.50 \mathrm{aA}$ & $7.75 \mathrm{aA}$ \\
\hline 3309 & $0.13 \mathrm{aA}$ & $0.17 \mathrm{aA}$ & $0.43 \mathrm{abA}$ & $44.65 \mathrm{aA}$ & $31.50 \mathrm{aA}$ & $95.26 \mathrm{abA}$ & $13.13 \mathrm{abA}$ & $7.75 \mathrm{aA}$ & $7.38 \mathrm{aA}$ \\
\hline Pinot Noir & $2.63 \mathrm{bA}$ & $3.35 \mathrm{bA}$ & $0.66 \mathrm{abB}$ & $131.92 \mathrm{aA}$ & $164.59 \mathrm{abA}$ & $102.79 \mathrm{abA}$ & $36.50 \mathrm{aA}$ & $107.25 \mathrm{bB}$ & $14.25 \mathrm{aA}$ \\
\hline Chardonnay & $15.63 \mathrm{cA}$ & $3.99 \mathrm{bB}$ & $1.54 \mathrm{aC}$ & $2,529.52 \mathrm{bA}$ & $625.16 \mathrm{bB}$ & $198.23 \mathrm{bC}$ & $242.88 \mathrm{cA}$ & $67.10 \mathrm{bB}$ & $29.50 \mathrm{aC}$ \\
\hline $\begin{array}{l}\text { Thompson } \\
\text { Seedless }\end{array}$ & $2.48 \mathrm{bA}$ & $0.17 \mathrm{aB}$ & $0.18 \mathrm{abB}$ & $120.01 \mathrm{aA}$ & $60.17 \mathrm{aA}$ & $113.31 \mathrm{abA}$ & $22.50 \mathrm{abA}$ & $17.63 \mathrm{aA}$ & $22.88 \mathrm{aA}$ \\
\hline
\end{tabular}

Data are the means of four replicates, in a duplicated experiment.

Upper case letters in rows show the differences between Meloidogyne species, and lower case letters in columns compare rootstocks and cultivars.

Means in columns or in rows followed by the same letter do not differ according to Tukey Multiple Range Test (P $\leq 0.05)$. 
M. ethiopica was the Meloidogyne species with the highest rate of reproduction with the three ungrafted cultivars, while $M$. hapla showed similar reproductive capacity as $M$. ethiopica with Pinot Noir.

Chardonnay was the most susceptible cultivar to the parasitism of M. ethiopica, since this species reached the highest number of galls, eggs and second stage juveniles of all the nematode-cultivar combinations $(\mathrm{P} \leq 0.05)$.

\section{Discussion}

Most published studies on rootstock resistance evaluation in grapevine host against Meloidogyne were performed with the four most common species, M. incognita, M. hapla, $M$. javanica and $M$. arenaria. M. ethiopica was identified in Chile in 2003, and in subsequent surveys, it was determined that it is present in most Chilean vineyards, in addition to tomatoes and other crops (Carneiro et al., 2007). Morphologically, its perineal patterns are similar to $M$. incognita and M. arenaria (Carneiro et al., 2004), which explains the misidentification in previous reports (Aballay et al., 1997; Alvarez, 2006).

According to our results, $M$. ethiopica is a more aggressive parasite, since the numbers of galls, eggs and second stage juveniles were higher than the other two species. All of the tested rootstocks supported low rates of reproduction for all three Meloidogyne species, implying that they are resistant, since they limit the reproduction of the nematodes by $90 \%$ compared with the most susceptible cultivar (Taylor and Sasser, 1983; Trudgil, 1991). Working on resistance mechanisms in woody hosts (Prunus), Marull et al., (1994), reported that root-knot nematodes were able to penetrate the roots in resistant rootstocks but most did not complete their life cycle. Those findings could explain the low numbers of nematodes found at the end of our experiment on Vitis host.
Edwards (1989) notes that SO4 and K 5BB are resistant to M. javanica; however, Dalmasso and Cuani (1976) report that SO4 is susceptible to $M$. hapla. In our study, all three rootstocks supported significantly lower rates of reproduction than the ungrafted cultivars.

Boubals (1979) classifies 101-14 as resistant to $M$. javanica, the same response as in our study. Meanwhile, Moura et al. (2014) note that this rootstock and $\mathrm{K}$ 5BB are resistant to $M$. incognita and M. javanica.

Muñoz and Gonzalez (2000) described the rootstock 3309 as being susceptible to the parasitism of most species of Meloidogyne. In our study, this rootstock showed a low number of galls and juveniles, but the number of eggs was similar to Thompson Seedless and Pinot Noir when infested with $M$. javanica, which could mean that this rootstock may be susceptible when a mixture of species that includes $M$. javanica is present. In previous studies, Mancilla (2004) concluded that under field and glasshouse conditions, SO4, 101-14, Kober 5BB were resistant, while 3309 was more susceptible to $M$. ethiopica.

In other studies (Mckenry and Anwar, 2006) classified 3309 as susceptible to pure populations or mixtures of M. incognita, M. arenaria and M. javanica, indicating however, that the plants exhibited good growth due to the higher vigor of this rootstock. SO4 was classified as resistant to all three species in the same study.

Cultivars were more susceptible to the three Meloidogyne species compared with the rootstocks. The higher sensitivity of Chardonnay to Meloidogyne spp. has been reported previously (Aballay et al., 1997), where $>65 \%$ of roots developed galls when infested with a mixture of species. This higher susceptibility is shown by the number of galls and also by their larger sizes (Alvarez, 2006). 
Pinot Noir has been reported as a susceptible cultivar to Meloidogyne spp. (Vieira, 1979). However, when compared with Chardonnay reproduction rates, it may be classified as a moderately susceptible cultivar (Taylor and Sasser, 1983).

The response of Thompson Seedless supporting lower rates of reproduction compared with the other two cultivars has been reported previously by Melakeberhan and Ferris (1988) and Walker et al., (1994) for M. incognita and M. arenaria and indicate that this cultivar may be considered moderately resistant to both species (Taylor and Sasser, 1983). According to our results, Thompson Seedless shows a similar reaction when challenged with $M$. ethiopica, which is interesting, considering that this is the most widely distributed species in Chilean vineyards.

The use of rootstocks is a necessary tool to manage the populations of nematodes, irrespective of the fact that they support a limited level of nematode reproduction. Data from Spain (Téliz et al., 2007; Gutiérrez-Gutiérrez et al., 2011) indicate that $M$. arenaria, M. incognita and $M$. javanica, and the dagger nematode $X$. index, have a reproductive rate higher than 1 in several Vitis rootstocks evaluated, including SO4 and $1103 \mathrm{P}$, indicating that these rootstocks are suitable hosts for nematode reproduction. However, cultivars such as Cabernet Sauvignon support higher levels of reproduction ( $~ 8-10$ times) compared with the evaluated rootstocks.

In conclusion, these findings suggest that the rootstocks SO4, K 5BB, $1103 \mathrm{P}$ and 101-14 can be grafted with grape cultivars and planted in soils with either a pure populations or a mixture of the species M. ethiopica, M. hapla and M. javanica. These rootstocks are not immune, but they are more resistant than ungrafted cultivars. Additionally, the response of Thompson Seedless suggests that it may be planted ungrafted in soils with a low population density of Meloidogyne spp.

\section{Resumen}

E. Aballay y O. Vilches. 2015. Resistencia de portainjertos de vid utilizados en Chile a los nematodos de la raíz Meloidogyne ethiopica, M. hapla y M. javanica. Cien. Inv. Agr. 42(3): 407-413. Los portainjertos 1103 P, 101-14, K 5BB, SO4, 3309, de uso frecuente para la plantación de vides en Chile, fueron evaluados para determinar su resistencia a tres especies de nematodos del género Meloidogyne, M. ethiopica, la especie de mayor frecuencia en viñedos en Chile, M. hapla y M. javanica. Junto con ello se evaluó la susceptibilidad de tres cultivares no injertados, Thompson Seedless, Pinot Noir y Chardonnay. Para ello, al inicio de la primavera, plantas nuevas de 2 meses de desarrollo producidas a partir de estacas, cultivadas en macetas de $3 \mathrm{~L}$ con sustratos estéril, fueron inoculadas con 5.000 huevos por maceta y mantenidas en un sector habilitado con malla raschel durante 6 meses. Para determinar su resistencia, al término del período de cultivo las plantas se sacaron de las macetas y se determinó su peso radical, número de agallas por masa de raíz, cantidad de huevos por gramo de raíz y número de juveniles de segundo estado en el suelo. Los resultados mostraron que los cinco portainjertos se comportaron como resistentes al ataque de las tres especies de Meloidogyne. De las variedades cultivadas, Chardonnay mostró una alta susceptibilidad, especialmente frente a M. ethiopica, Pinot Noir se comportó moderadamente susceptible, en tanto que, Thompson Seedless mostró una resistencia moderada.

Palabras claves: Nematodos fitoparásitos, plagas de raíces, Vitis vinifera, viñas. 


\section{References}

Aballay, E., P. Persson, and A. Mårtensson. 2009. Plant-parasitic nematodes in Chilean vineyards. Nematropica 39: 85-98.

Aballay, E., R. Baettig, and A. Vieira. 1997. Evaluación de la tolerancia de ocho portainjertos de vid al nemátodo del nódulo de la raíz (Meloidogyne spp.). Aconex 56: 15-21.

Alvarez, P. 2006. Evaluación de algunas alternativas de control sobre el nemátodo del nódulo de la raíz (Meloidogyne spp.), como opciones de preplantación en condiciones de replante en vid (Vitis vinifera L.). Memoria Ingeniero Agrónomo. Universidad de Chile, Facultad de Ciencias Agronómicas. Santiago, Chile. 24 pp.

Boubals, D. 1979. Situation des porte-greffes resistant aux nematodes ravageurs directs. Bulletin de l'O.I.V. 52(578): 263-271.

Carneiro, R.M.D.., M.R. Almeida, E.T. Cofcewicz, J.C. Magunacelaya, and E. Aballay. 2007. Meloidogyne ethiopica, a major root-knot nematode parasitising Vitis vinifera and other crops in Chile. Nematology 9: 635-641.

Carneiro, R.M.D., O. Randig, M.R. Almeida, and A.C.M.M. Gomes. 2004. Additional information on Meloidogyne ethiopica Whitehead, 1968 (Tylenchida : Meloidogynidae ), a root-knot nematode parasitising kiwi fruit and grape-vine from Brazil and Chile. Nematology 6: 109-123.

Dalmasso, A., and A. Cuani. 1976. Resistance des porte-greffes de vignes a differentes populations du nematodo Meloidogyne hapla. Progres Agricole et Viticole 93(25): 800-807.

Edwards, M. 1989. Resistance and tolerance of grapevine rootstocks to plant parasitic nematodes in vineyards in north-east Victoria. Aust. J. Exp. Agric. 29: 129-131.

Gutiérrez-Gutiérrez, C., J.E. Palomares-Rius, R.M. Jiménez-Díaz, and P. Castillo. 2011. Host suitability of Vitis rootstocks to root-knot nematodes (Meloidogyne spp.) and the dagger nematode Xiphinema index, and plant damage caused by infections. Plant Pathol. 60: 575- 585.

Hussey, R.S., and K.R. Barker. 1973. A comparison of methods of collecting inocula of Meloidogyne spp including a new technique. Plant Dis. Report. 57(12): 1025-1028.

Mancilla, R. 2004. Evaluación de la resistencia de seis portainjertos de vid al nemátodo de la raíz Meloidogyne ethiopica, Whitehead, 1968 en condiciones de campo e invernadero. Memoria Ingeniero Agrónomo. Universidad de Chile, Facultad de Ciencias Agronómicas. Santiago, Chile. 53 pp.

Marull, J., J. Pinochet, A. Felipe, and J. L. Cenis. 1994. Resistance verification in Prunus selections to a mixture of 13 Meloidogyne isolates and resistance mechanisms of a peach-almond hybrid to M. javanica. Fund. and Appl. Nematol. 16:85-92.

Mckenry, M.V., and S.A. Anwar. 2006. Nematode and grape rootstock interactions including an improved understanding of tolerance. J. Nematol. 38: 312-318.

Melakeberhan, H., and H. Ferris. 1988. Growth and Energy Demand of Meloidogyne incognita on susceptible and resistant Vitis vinifera cultivars. J. Nematol. 20(4): 545-554.

Montealegre, J., E. Aballay, S. Sanchez, L. Rivera, and A. Pino. 2009. Hongos y nematodos fitopatógenos asociados al sistema radical en uva de mesa en la III Región de Chile. Aconex 103: 5-9.

Moura, M.F., M.A. Tecchio, C.R. Dias-Arieira, H.H. Puerari, and F.M. Chiamolera. 2014. Reaction of grape rootstocks to Meloidogyne incognita and M. javanica. Acta Hortic. 1046: 109-112.

Muñoz, I., and H. González. 2000. La utilización de portainjertos marcará el futuro de la viticultura chilena. Aconex 68: 10-13.

Roberts, P. 1995. Conceptual and practical aspects of variability in root-knot nematode related host plant resistance. Ann. Rev. Phytopathol. 33:199-221.

Scheck, H., S.J. Vasquez, D. Fogler, and W.D. Gugler. 1998. Grape growers report losses to blackfoot and grapevine decline. Calif. Agric. 52(4): 19-23.

Southey, J.F. 1986. Laboratory methods for work with plant and soil nematodes In: J.F. Southey (ed.). Her Majesty`s Stationary Office, London.

Taylor, A. L., and J. N. Sasser. 1983. Biología, identificación y control de los nemátodos de nódulo de la raíz (especies de Meloidogyne). Ed. U. Carolina del Norte. 111 pp. 
Téliz, D., B. Landa, H.F. Rapoport, F. Pérez, R. Jiménez-Díaz, and P. Castillo. 2007. Plant-parasitic nematodes infecting grapevine in southern Spain and susceptible reaction to root-knot nematodes of rootstocks reported as moderately resistant. Plant Dis. 91: 1147-1154.

Trudgill, D. 1991. Resistance and tolerance of plantparasitic nematodes in plants. Ann. Rev. Phytopathol. 29: 167-192.
Vieira, A. 1979. Resistencia aparente de algunos portainjertos de la vid al ataque de nemátodos del nudo de la raíz (Meloidogyne sp.). Invest. Agríc. 5(2): 93-95.

Walker, M.A., H. Ferris, and M. Eyre. 1994. Resistance in Vitis and Muscadinea species to Meloidogyne incognita. Plant Dis. 78: 10551058. 
